\title{
Tracking rapid geological change
}

\author{
528 Paradise Street, Victoria BC V9A 5E2, Canada.
}

Assessing the health and condition of ecosystems and the environment in general require an ability to track important changes that take place in decades or shorter periods. Recognizing the importance of short-term geological change can assist in understanding and coping with environmental change, whether local or global. It can also challenge common perceptions about the stability of nature and raise some difficult questions about whether causes are human-induced or natural. As a tool for monitoring rapid geological change, the geoindicator approach is finding increasing application in a range of situations. Under the sponsorship of IUGS, the Geoindicator Initiative (GEOIN, www.geoindicator.org) is now engaged in an ambitious program of activities to refine and disseminate the concept.

\section{Assessing environmental sustainability}

In many parts of the world, the search is on for a better, "gentler" way to live with nature, and there is a deep and genuine longing for more sustainable societies, characterized by systems that last and whose benefits are shared equitably. Achieving any kind of sustainability requires the capacity to assess current conditions and trends, so that policies and practices can be tested and revised as needed. Much effort is now being devoted to developing standard indicators with which to assess social and environmental conditions (e.g. Moldan et al. 1997, World Economic Forum 2000, Schiller et al. 2001), and state-of-the-environment reporting has now become commonplace (Hamblin 1998, Clark 1999, Parks Canada 2000, Worldwatch Institute 2002). In the past decade, several hundred such reports have been published for continental regions, nations, national park systems and even individual cities (e.g. Dushanbe, Capetown, Geneva-see www.ceroi.net). The general aim is to assess and report on what is happening in the environment (its state), the significance and causes of any changes, and the usefulness of environmental policies and actions. Are physical, chemical and biological pressures on the environment increasing or decreasing, and if so in what ways? Are the health and integrity of ecosystems being maintained, reduced or enhanced?

Geological processes have operated since the early days of the Earth, and have set the scene for the development of life itself. The ultimate driving forces have been either external to the lithosphere and primarily climatic, or internal and related to heat flow and energy fluxes from beneath the Earth's surface. However, ever since life began and multiplied there have been intricate interactions between organisms and soils, rocks, water and air. We humans have now also become geological agents, far more potent and quick-acting than any other species in the past. The pace of geological and ecological change has increased drastically, at least in comparison to the past 10,000 years of the Holocene.

Geologists have always taken the long-term view-we invented "deep time" long before the cosmologists began to look outwards in space and backwards in time. This may be one reason why geology has tended to be marginalized in matters related to environmental change where the time-scale of concern is years, decades, or perhaps a few centuries. Yet, there are many examples of geological change that take place in minutes (landslides, earthquakes), days (floods), weeks (eruptions, dust storms), or a year or
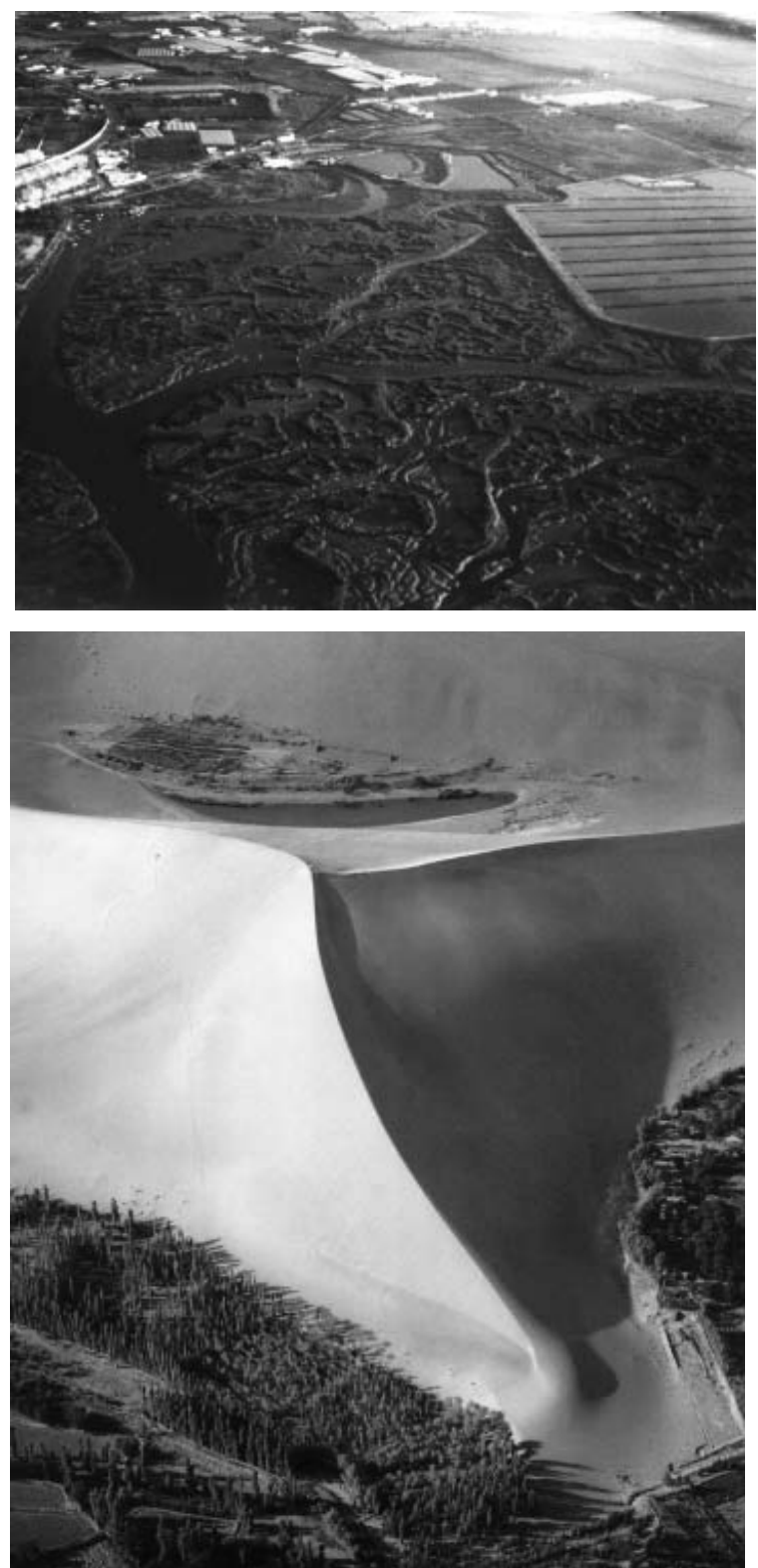

Figure 1 Where geology and ecology intersect. Above: Intertidal wetlands of the Ria Formosa Nature Park, southern Portugal. Changes in relative sea level, coastal subsidence, and the quality of surface water that drains from the nearby industrial city of Faro will all have effects on wetland ecosystems. Below: Star dune and interdune lake in the Hexi Corridor of NW Gansu, China. Sand transport is likely to affect both lake and agricultural ecosystems (from Zuo and Xing, 1992). 
two (glacier flow/melting, decline of water levels), all of which can have a profound effect on landscapes and ecosystems. No organism or ecosystem can exist or function without drawing upon abiotic components in rocks, soils, air and water. Obviously then, in assessing the condition and health of ecosystems and the environment in general, the non-biological components must be taken into account, especially those that are liable to rapid and dynamic change (Figure 1). It is for this purpose that geoindicators were developed, in an attempt to bring together in one convenient format all the important ways in which rapid change takes place in the physical landscape, regardless of the cause.

\section{What are geoindicators?}

Geoindicators are defined as magnitudes, frequencies, rates or trends of geological processes and phenomena that occur at or near the Earth's surface and that are significant for assessing environmental change over periods of 100 years or less (Berger and Iams, 1996). They are high-resolution measures of short-term, dominantly non- biological changes in the geological environment, many of which can cause irreversible ecosystem disturbance on one scale or another. They include both rapid, catastrophic events and the more pervasive, slow-onset changes that are generally evident within a human lifespan. Important but slower earth processes, such as plate tectonics, basin subsidence, hydrocarbon and mineral formation, and diagenesis, are excluded.

Geoindicators themselves are not new. They are all based on standard methods and monitoring procedures. What is new is the attempt to bring all them into a common conceptual framework, designed to emphasize to non-geologists the importance of including rapid geological change in environmental assessments. After extensive review of significant parameters for terrestrial and coastal areas, the International Union of Geological Sciences selected twentyseven geoindicators (Table 1, and see Figure 2 for examples of familiar geoindicators) and compiled them in an annotated checklist. Together they constitute a kind of landscape metric, a collection of tools for assessing abiotic changes to landscapes (www.geoindicator.org; see www.gcrio.org/geo/toc.html for the complete checklist). Monitoring geoindicators is generally non-destructive and has the advantage of little environmental impact. Most geoindicators can be

Table 1 Geoindicators (bold) and some environmental changes they reflect, in addition to climate change.

Cryosphere

- Frozen ground activity—surface and groundwater hydrology, permafrost melting, land surface degradation

- Glacier fluctuations - precipitation, insolation, river runoff

Arid \& Semi-Arid Zones

- Desert surface crusts \& fissures—aridity

- Dust storm magnitude, duration, \& frequency — dust transport, aridity, land use

- Dune formation \& reactivation-wind speed and direction, moisture, sediment availability

- Wind erosion-land use, vegetation cover

\section{Marine \& Coastal Zones}

- Coral chemistry \& growth patterns - surface water temperature, salinity

- Relative sea level — coastal subsidence and uplift, fluid withdrawal, sedimentation and compaction

- Shoreline position - coastal erosion, land use, sea level, sediment transport and deposition

\section{Lakes}

- Lake levels \& salinity—land sue, streamflow, groundwater circulation

Wetlands

- Wetland extent, structure \& hydrology—land use, biological productivity, streamflow

\section{Rivers \& Streams}

- Streamflow-precipitation, basin discharge, land use

- Stream channel morphology — sediment load, flow rates, land use, surface displacement

- Stream sediment storage \& load—sediment transport, flow rates, land use, basin discharge

\section{Surface \& Groundwater}

- Karst activity_-groundwater chemistry and flow, vegetation cover, fluvial processes

- Surface water quality-land use, water-rock-soil interactions, flow rates

- Groundwater quality—land use, pollution, rock and soil weathering, acid precipitation, radioactivity

- Groundwater chemistry in the unsaturated zone-weathering, land use

- Groundwater level-abstraction, recharge

\section{Soils}

- Soil quality—land use, chemical, biological and physical soil processes

- Soil \& sediment erosion — surface runoff, wind, land use

\section{Natural Hazards}

- Seismicity—natural and human-induced release of earth stresses

- Landslides \& avalanches — slope stability, mass movement, land use

- Volcanic unrest - near-surface movement of magma, heat flow, magmatic degassing

\section{Other}

- Sediment sequence \& composition-land use, erosion and deposition

- Surface displacement-land uplift and subsidence, faulting, fluid extraction

- Subsurface temperature regime-heat flow, vegetation cover, land use 

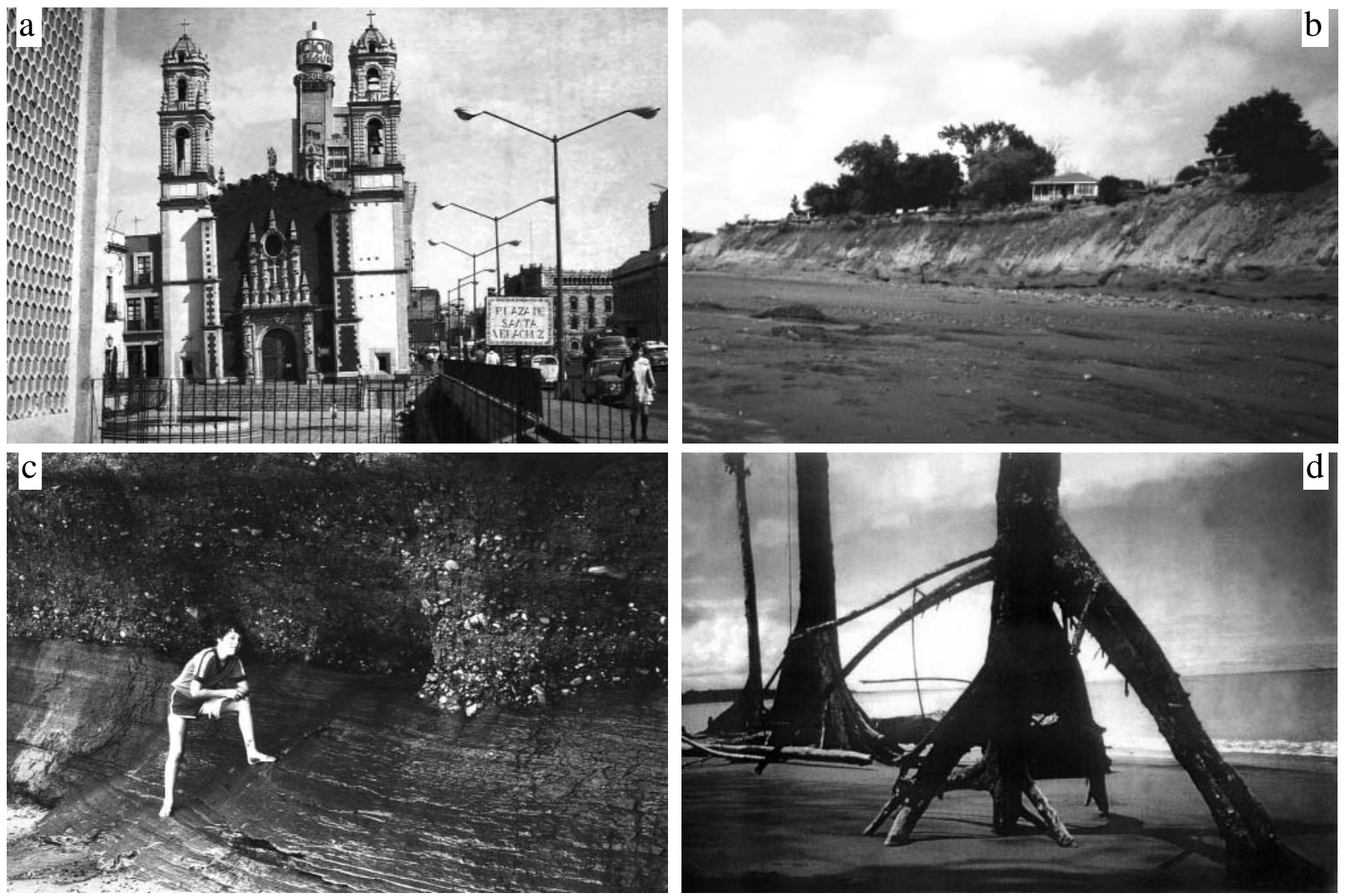

Figure 2 Examples of common geoindicators.

a) Surface Displacement: Ground tilting due to groundwater withdrawal, Mexico City.

b) Shoreline Position: Rapidly-eroding (15-30 cm/yr) coastal cliffs, Kingsport, Nova Scotia, Canada. The house, which when built in 1910 was separated from the escarpment by an ample front yard, is now in danger of collapsing over the cliff.

c) Groundwater quality: Groundwater seep on coastal cliffs beneath intensively farmed land, Annapolis Valley, Nova Scotia. The effect on this seep of agricultural pesticides and herbicides has not been determined.

d) Relative Sea Level\& Shoreline Position: Mangroves stranded due to recent drop in sea level and retreat of shoreline. Playa Churimal, San Juan River Delta, Colombia (Gloria Lopez).

tracked by inexpensive means, though some, such as the quality (chemistry) of soil, groundwater, and surface water may require complex and costly analyses. Some are quite simple, such as shoreline position, presence and condition of desert surface crusts, or groundwater level. Others are composites of many related processes-karst activity, frozen ground activity, and volcanic unrest.

By including measures of past change, such as coral growth rings and annual sediment layers in lakes and reservoirs, geoindicators help to emphasize the importance of the recent geological archive for environmental monitoring. The task of establishing baseline trends is easier now that paleoenvironments can be deduced from ice cores, lake sediments, speleothem, and other proxies, with the kind of resolution that is useful for assessing short-term change. Such geoindicators can function as inexpensive, automatic, field recorders that can be "played back" to extract information on environmental change (Shen, in Berger and Iams 1996), just as tree-ring records are now being read.

Although the emphasis here is on abiotic change, biological and geological systems interact intimately in time and space, and it is not possible to ignore living organisms. This is especially so when dealing with deposits of organic origin such as peat and soil, the influence of animals and plants on weathering, erosion and deposition, or microbiota that play a mediating role in groundwater chemistry and karst processes.
One problem in compiling any such checklist or matrix is that the impression may be given of separate compartments with little interaction. Yet, chemical loads and fluctuations in surface water and groundwater, soils, biota and the atmosphere are intimately linked, and variations in one commonly affect others. For example (see Figure 3), coastal subsidence (the surface displacement geoindicator) may be part of the same overall situation-as in river deltas-that involves changes in river channel morphology (streamflow and stream channel morphology), loss of nearby wetlands (wetlands extent, structure, water budget and geochemistry), river sediment load (stream sediment storage and discharge), local sea level (relative sea level), and the morphology and location of the shore (shoreline position). Moreover, natural patterns are often over-ridden by human influences. Nevertheless, the checklist responds to the need to start at some simple and basic level.

Note that the term "indicator" has occasionally been used to describe geological features that point to or stand as proxies for other aspects of geological structure, lithology or history. For example, a geophysical anomaly may be used to indicate the possible presence of ore deposits, glacial striae to indicate ice movement direction, or the chemistry of sediments to provide information about duration of surface weathering (eg. Chikishev 1973; Kujansuu and Saarnisto 1990; Gregorauskiene and Kadunas 2000). However, geoindicators per se refer to the results of change on a decadal, annual, or even shorter time-scale. 


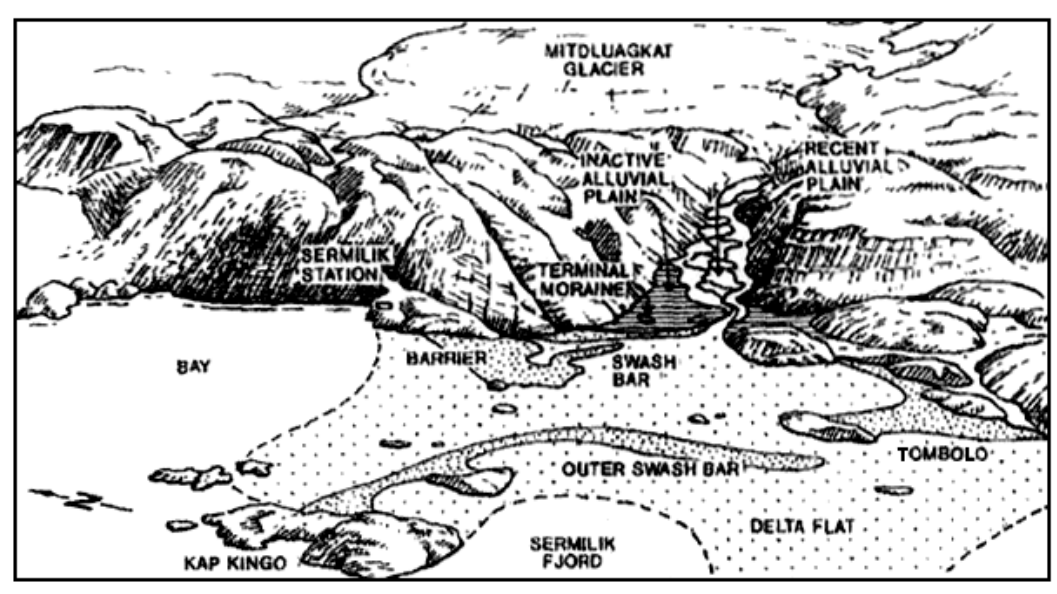

Figure 3 The Mitdluagkat Glacier (Ammassalik, SE Greenland) feeds a river, which deposits sediments in a complex delta, with changing shorelines. Fluctuations in glacier terminus and mass balance will effect streamflow and sediment load, which may in turn affect shoreline location and coastal landforms. Distance from river mouth to glacier snout is $1.6 \mathrm{~km}$. (after M. Rasch et al, in Berger and Iams, 1996).

\section{Applying geoindicators}

There is a long history of more-or-less systematic tracking of geoindicators, for example within the contexts of monitoring rivers, water quality, glaciers and ice sheets, and sea level. As the importance of keeping a "watching brief" on rapid geological change in landscapes becomes more widely recognized, many other applications are coming to light. Following are some examples now in press.

- Klimas and Gregorauskas see groundwater as a valuable geoindicator of environmental condition. They show the importance of tracking changes in groundwater levels (reflected for example in wetland drainage and loss of surface runoff), groundwater quality (including encroachment of saline formation waters and saltwater intrusion), and water-rock interactions (resulting in karstification and land subsidence).

- The gypsum and dolomite karst landscape of northern Lithuania is one subject to continual change in hydrological parameters and in surface features. Taminskas and Marcinkevicius describe a recent monitoring program which is tracking both meteorological conditions and rapid changes over the past several decades in river runoff, water chemistry and sinkhole formation. They use the amount of dissolved gypsum removed by underground and surface runoff to calculate an overall rate of chemical denudation, an approach that can help environmental managers to assess karst activity.

- Tavast and Raukas summarize the results of many years study of the variations in the level of Lake Peipsi, which lies along much of the border between Estonia and Russia. Lake Peipsi has a long history of coastal inundation, due in part to post-glacial rebound such that its northern part is rising and southern portion sinking. As water spreads southwards, large areas have become flooded, and there are other changes related to climate, such as the action of lake ice, to which local residents must adjust.

- In describing coastal changes in the Orinoco River delta, Morton points to the importance of lateral zonations and temporal successions of vegetation in tracking recent changes in river levels. There are also a wide range of landforms and deposits, which, though they may take longer than 100 years to develop, help to determine baseline conditions and trends of geological change.

- McCarthy reviews several parameters important for tracking rapid geological change in alpine regions, including glacier fluctuations, lake levels, and landslides and avalanches. He points out the value of dendrochonology and lichenometry for establishing baseline trends.
- Ozaki and Higgins show how the geoindicator concept is helping park managers to recognize the importance of geological monitoring in assessing the health and condition of national parks in the USA (see also Shaver and Wood, 2001). A similar search is underway for a set of geoindicators for use in national parks in Canada (Welch).

- Geoindicators are also helping to stress the importance of including geological processes in state-of-the-environment reporting (Australia, British Columbia), and in assessing the contribution of mining to environmental sustainability in North America (see http://www.iied.org/mmsd/index.html).

\section{The causes and importance of rapid geological change}

The geoindicator checklist summarizes the many ways in which landscapes can change, whatever the cause. It can be very difficult to distinguish changes induced by human actions from those that might have taken place anyway by natural processes. For example, a particular change in the shape and dimensions of stream channels or the capacity of rivers to store and discharge sediments might be a result of dams and reservoirs, irrigation systems, and river diversions. Or it could be the result of rainfall and flash floods, failure of watershed slopes, variations in the supply of source sediments or a consequence of the internal dynamics of fluvial flow (Figure 4). Ground subsidence, seismicity, and slope failure are all natural processes that can also be triggered directly or indirectly by human action. Indeed volcanism is probably the only rapid geological process that is unaffected directly or indirectly by human activities.

The distinction of human from non-human causes of landscape change is fundamental to environmental management and decisionmaking. Trying to stop natural processes may be both futile and harmful to ecosystem well-being - as in the former North American public campaign to eradicate the forest fires that are now known to be essential to natural forest renewal. Policies and declarations that aim to change human behaviour may also be misguided when they assume that nature left alone is inherently stable, in equilibrium and "benevolent" to life. A seminal expression of this is Aldo Leopold's famous dictum "A thing is right when it tends to preserve the integrity, stability and beauty of the biotic community. It is wrong

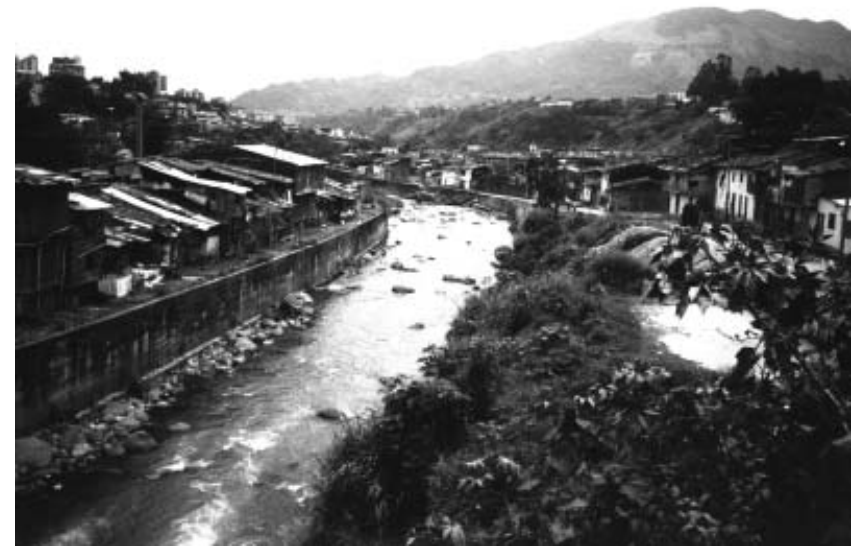

Figure 4 A stream through a shantytown on the outskirts of Pereira in the central Andes of Colombia. Frequent floods damage low-lying houses, reduce water quality and cause collapse of river banks, with obvious effects on streamflow, stream sediment storage and load, and surface water quality geoindicators. 
when it tends otherwise" (1968, p 224). What could be less "right" from the viewpoint of organisms on island communities than submergence by sea level rise or, for that matter, of whole species than extinction en masse by extraterrestrial impacts? The Earth Charter, a valiant attempt to draft a global ethic for a more sustainable future, also speaks of protecting and restoring the integrity of ecosystems and of preventing harm as the "best method of environmental protection" (www.earthcharter.org). Underlying these and other statements appears again to be a belief that change (disturbance), which is commonly harmful, is not part of the natural background to the ecosphere (see Berger 1999).

Canadian law now requires Parks Canada to maintain the ecological integrity of its national parks. This is "achieved when ecosystem structures and functions remain unimpaired by human-caused stresses and native species are present at viable population levels" (Woodley 1996). The implication seems to be that there is no loss of integrity when natural stresses impair ecosystems. Another objection arises from the legal definition that ecological integrity is "a condition that is determined to be characteristic of its natural region and likely to persist, including abiotic components" (Canada National Parks Act 2000). Here the emphasis is on conditions that last. In both definitions there is a difficult problem in reconciling the reality of short-term and long-term change with the management goal of continuity, even allowing for limited change within system boundaries (Berger 1998). There can be little integrity remaining in a tropical island ecosystem drowned by rising sea level, or in a savannah overrun by migrating sand dunes.

Recognizing the importance of rapid natural geological change also raises problems for the now standard pressure-state-response framework for indicators used by the UN and many national organizations in assessing environmental sustainability and the state of the environment (Berger and Hodge 1998). In this framework, stresses (or driving forces) are generally limited to those due to human actions. Processes such as coastal erosion and subsidence are ignored, even though they can also stress local environments and ecosystems.

As the 2001 Amsterdam Declaration on Global Change puts it, "The Earth System behaves as a single, self-regulating system comprised of physical, chemical, biological and human components. Earth System dynamics are characterized by critical thresholds and abrupt changes. Global change cannot be understood in terms of a simple cause-effect paradigm" (www.sciconf.igbp.kva.se). The difficulty in separating human-induced from natural environmental change does not make any easier the management of landscapes and urban areas, but ignoring natural forces in policy and practice, would seem to guarantee failure.

\section{Summing up}

Geoindicators can help to provide an answer to the question "What needs to be monitored, tracked, assessed in the physical environment?" On what abiotic landscape components should environmental managers keep a watching brief? Geoindicators help to guide and remind those in charge of tracking landscape, ecosystem and environmental health and condition of the importance of rapid geological change.

Since the Checklist was first published in 1996 and posted on the Internet (www.gcrio.org/geo/title.html), the approach has been gaining in acceptance and application. Following meetings in Malaysia, Lithuania, Poland, Zambia and Newfoundland, the IUGS Geoindicators Initiative (GEOIN) is now organizing an ambitious five year program of workshops, short courses, publications and other activities to disseminate and refine the approach. The longrange goal is to underscore the importance of recognizing and tracking rapid geological change in environmental policy and practice.

\section{Acknowledgments}

The geoindicators approach is a collective effort by many earth scientists working initially under the umbrella of the IUGS Commission on Geological Sciences for Environmental Planning. Details of the current effort to disseminate and refine the concept can be found at www.geoindicator.org, hosted by the Geological Survey of Lithuania, and expressions of interest in geoindicator activities are invited. GEOIN activities are made possible by funding from IUGS, the Geological Society of America, Newkirk, Engler and May Foundation, and many other organizations. I am grateful to Jonas Satkunas (Geological Survey of Lithuania), Peter Bobrowsky (Geological Survey of Canada), Waite Osterkamp (US Geological Survey), and Colin Simpson (Chairman, COGEOENVIRONMENT) for much advice and support.

\section{References}

Berger, A. R., 1999, COGEOENVIRONMENT considers and proposes revisions to the Earth Charter: COGEOENVIRONMENT Newsletter 14, January 1999 , pp. 6-8.

Berger, A. R., 1998, Environmental change, geoindicators and the autonomy of nature: GSA Today, vol. 8, pp. 3-8.

Berger, A. R., and Hodge, R. A., 1998, Natural change in the environment: a challenge to the pressure-sate-response concept: Social Indicators Research, vol 44, pp. 255-265.

Berger, A. R. and Iams, W. J., eds, 1996, Geoindicators-assessing rapid environmental changes in earth systems: Rotterdam, A.A. Balkema, 466p.

Chikishev, A. G., ed.,, 1973, Landscape indicators: new techniques in geology and geography: New York, Consultants Bureau, Plenum Press, 178p

Clark, R., 1999, Global Environment Outlook 2000: London, Earthscan Publications, 250p.

Gregorauskiene, V., and Kadunas, V., 2000, Chemical composition of soil and lake sediments - an indicator of geological processes in Lithuania: Geological Quarterly (Warsaw), vol 44, no. 4, pp. 347-354.

Hamblin, A., 1998. Environmental indicators for national state of the environment reporting - the land: Canberra, State of the Environment (Environment Indicator Reports), Department of the Environment, 124p.

Klimas, A., and Gregorauskas, M., Groundwater abstraction and contamination in Lithuania as geoindicators of environmental change: Environmental Geology (in press).

Kujansuu, R., and Saarnisto, S. M., eds, 1990, Glacial indicator tracing: Rotterdam, A..A. Balkema, 160p.

Leopold, A., 1968, A Sand County almanac and sketches from here and there: London, Oxford University Press, 226p.

McCarthy, D., Ozaki, V., and Welch, D., Identification and use of geoindicators in Glacier and Mount Revelstoke National Parks: in Berger, A.R. and Liverman, D.G., eds, Geoindicators for ecosystem monitoring in parks and protected areas. Halifax: Parks Canada Ecosystem Science Review Reports 018, pp.38-42.

Moldan, B., Billharz, S., and Matravers, R. eds, 1997, Sustainability Indicators. Report of the Project on Indicators of Sustainable Development: SCOPE Report 58. Chichester, John Wiley and Sons, $415 \mathrm{p}$.

Morton, R. A., Coastal geoindicators of environmental change in the humid tropics: Environmental Geology (In press).

Ozaki, V., and Higgins, B., Application of geoindicators in U.S. national parks-use of geoindicators to identify human influences on geologic processes, in Berger, A.R. and Liverman, D.G. eds, Geoindicators for ecosystem monitoring in parks and protected areas. Halifax: Parks Canada Ecosystem Science Review Reports 018, pp.17-26.

Parks Canada 2000, State of Protected Heritage Areas 1999 Report: Ottawa, Parks Canada Agency, 85p.

Shaver, D. B., and Wood, J., 2001, Geology in the National Park Service: Geotimes, vol 46, no. 4, pp. 14-19

Schiller, A., Hunsaker, C. T., Kane, M. A., Wolfe, A. K., Dale,V. H., Suter, G. W., Russell, C. S., Pion, G., Jensen, M. H., and Konar, V. C., 2001, Communicating ecological indicators to decision makers and the public: Conservation Ecology, vol. 5, no.19. [online] URL: http://www.consecol.org/vol5/iss1/art19.

Taminskas, J., and Marcinkevicius V., Karst geoindicators of environmental change: the case of Lithuania: Environmental Geology (in press). 
Tavast, E. and Raukas, A., Rapid changes on the coast of Lake Peipsi, and their environmental consequences: Environmental Geology (in press).

Welch, D., Geoindicators for monitoring the state of Canada's national parks - a proposal: in Berger, A.R. and Liverman, D.G. eds, Geoindicators for ecosystem monitoring in parks and protected areas. Halifax: Parks Canada Ecosystem Science Review Reports 018, pp.12-16.

World Economic Forum, 2001, 2001 Environmental Sustainability Index: New Haven, Yale University Center for Environmental Law and Policy, 253 p.

Worldwatch Institute, 2002, State of the World 2002: New York, W.W Norton and Co., 265p.

Woodley, S., 1996, A scheme for ecological monitoring in national parks and protected areas: Environments Journal, vol. 23, pp. 50-73.

Zuo, D., and Xing, Y., eds, 1992, The natural features of China: Beijing: China Pictorial Publishing House, 319p.
Tony Berger (Victoria, $B C$. Canada.aberger@uvic.ca) is a CoDirector of the IUGS Geoindicators Initiative. He has taught geology in Canada, the UK and Sri Lanka, and is a former Editor of Episodes, and founding Secretary-Treasurer of AGID. Once a researcher on granites and crystalline rocks, he is now more interested in rapid environmental change and its implications for environmental thinking and policy.

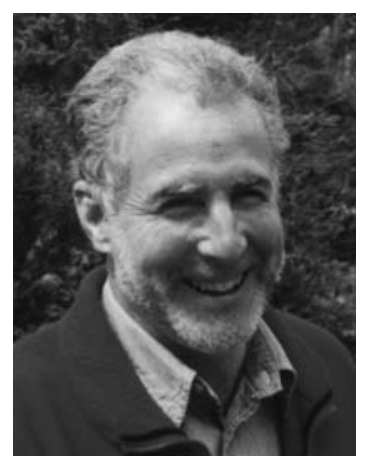

\section{Hutchison 'Young Scientist' Fund}

William Watt Hutchison, "Hutch" to his many friends around the world, was a Scots-born Canadian geologist who served Canada and the IUGS in myriad dynamic and creative ways. Most notably, he served as the IUGS Secretary General (1976-1980) at a pivotal time in its history, and as IUGS President (1984-1987). The same boundless energy, enthusiasm, skill in communications, and ability to foster teamwork that characterized his work with the IUGS also carried him to preeminent scientific administrative positions in the Canadian Government, where he served as Director General of the Geological Survey of Canada and as Assistant Deputy Minister of Earth Sciences. His distinguished career was terminated in 1987 by his untimely death at the age of 52, following a painful struggle with cancer.

One of Hutch's last wishes was to establish under IUGS auspices a memorial foundation intended to promote the professional growth of deserving, meritorious young scientists from around the world by supporting their participation in important IUGS-sponsored conferences. The first 3 beneficiaries of the Hutchinson "Young Scientist Foundation" attended the 28th International Geological Congress (IGC) in Washington, D.C., in 1989. However, income earned as interest on the Hutchison fund is insufficient to sustain comparable grants every four years without seriously eroding the principal. For that reason, the IUGS made no grants from the fund for the 29th and the 30th IGCs, preferring instead to strengthen the fund by allowing it to earn interest for a longer period of time and by appealing for donations from the international geologic community. And in 2000, 6 awardees received financial support from the Fund to attend the 31 st IGC in Rio de Janeiro, Brazil.

The Hutchison "Young Scientist Foundation" is a worthy cause that honors a fine, caring man and a distinguished, public-spirited scientist and administrator. The foundation also celebrates and promotes those things that gave Hutch the most professional satisfaction: geology, international scientific collaboration, and stimulating young minds.

The IUGS welcomes contributions to the Hutchison "Young Scientist Foundation." Please send donations to:

Dr. John A. Reinemund
945 Oakwood Lane
Myrtle Beach, SC 29572
Fax: 843-272-4128

Tel: 843-361-9074

Checks in US dollars or Visa/Mastercard (please include account number and expiration date) are preferred in order to avoid the high cost of currency conversions. Residents of the U.S.A. are reminded that charitable gifts of this nature are tax deductible. 